Стасюк Ю.М., кандидат історичних наук, начальник науково-дослідної лабораторії науково-дослідного центру воєнної історії НУО України імені Івана Черняховського (м. Küв);

Горєлов B.I., кандидат історичних наук, старший науковий співробітник науководослідної лабораторіі науково-дослідного центру воєнної історії НУО України імені Івана Черняховського (м. Київ)

\title{
РОЛЬ УКРАЇНСЬКИХ ДОБРОВОЛЬЧИХ ФОРМУВАНЬ У БОЯХ НА СХОДІ УКРАЇНИ (КВІТЕНЬ 2014 - ЛЮТИЙ 2015 рр.)
}

На основі вивчення відкритої різнопланової літератури виявлено, щэо узагальненого матеріалу про участь українських добровольчих формувань у боях на Сході Украйни немає. У статті подано визначення украйнських добровольчих формувань та їх характеристики. 3 антитерористичної операчії виокремлено основні бої, у яких брали участь добровольчі формування. Автори розглядають роль формувань у ході боїв, визначають умови, що сприяли успіху їх діяльності.

Ключові слова: украӥнські добровольчі формування, добровольчі батальйони (добробати), бойова діяльність, бої, антитерористична операчія на Сході України.

Українські добровольчі формування (УДФ), відомі ще як добровольчі батальйони, добробати, є унікальним явищем в антитерористичній операції (ATO) на Сході Україні та у військовій історії України XXI ст. Вивчення бойової діяльності УДФ у 2014-2015 рр., на нашу думку, сприятиме узагальненню бойового досвіду із захисту територіальної цілісності нашої держави та національно-патріотичному вихованню громадян України. 
На теперішній час існує низка публікацій, у яких розглядаються окремі аспекти зародження та створення УДФ $[1 ; 6 ; 7 ; 8]$. Проте роль добробатів під час боїв в АТО не була предметом поглибленого дослідження. У деяких працях автори розглядають цю проблему лише щодо поодиноких формувань чи побіжно [12; $13 ; 15 ; 19]$.

Мета статті - виявити значення УДФ у боях у районі АТО (квітень 2014 - лютий 2015 рр.).

Завданням статті $є$ розгляд участі УДФ у бойових діях у районі проведення АТО (квітень 2014 - лютий 2015 рр.), виявлення позитивних та негативних умов, що впливали на їх діяльність, на основі відкритих публікацій про збройний конфлікт на Сході України (ЗКСУ).

3 початком АТО з 14 квітня 2014 року самоорганізовані групи українських патріотів згуртовувалися, здобували зброю та з початку травня 2014 року почали проводити в окремих районах Донецької та Луганської областей так звані Рейди добровольців [8, с. 556-557].

Добровольчий рух - явище унікальне, яке на початку зіграло ледь не найважливішу роль у становленні лінії оборони на Донбасі [2]. Основою для створення українських добровольчих формувань стали загони Самооборони Майдану (Свромайдану) та громадські організації, які брали участь у Революції Гідності.

Тогочасний секретар Ради національної безпеки і оборони України Олександр Турчинов на презентації книги “Добробати” відзначив: “Добровольчі батальйони заклали ідеологію розвитку сильної незалежної України" [21]. У праці “Україна - Росія: війна в умовах співіснування" Г. Перепелиця зробив висновок, що діяльність добровольчих загонів (які пізніше стали відомими як батальйони “Азов”, “Донбас”, “Дніпро-1”), створених 3-поміж населення переважно східних областей України, була позитивною для України на першому етапі ЗКСУ [17, с. 592].

Як виявили автори статті, організаційно УДФ складали чотири основних різновиди збройних формувань: батальйони територіальної 
оборони 3С України, підрозділи патрульної служби особливого призначення MBC, резервні батальйони НГУ і власне добровольчі формування, які не увійшли до складу ЗС України, інших військових формувань та правоохоронних органів. Останні мали ознаки, що відрізняли їх від регулярних підрозділів та частин силових відомств [20, с. 107]. На середину серпня 2014 року чисельність осіб - учасників неофіційних добровольчих батальйонів у зоні АТО, які не підпорядковувалися штабу АТО і не входили до складу їх сил і засобів, а самостійно діяли на власний розсуд, становила близько 4 тис. осіб. У той же час чисельність особового складу ЗС України, МВС, СБУ, НГУ, ДПС України, які входили до складу сил і засобів штабу АТО, налічувала близько 40 тисяч осіб [3, с. $3 ; 17$, с. 618].

У зазначений період УДФ провели багато боїв. Варто виділити ті, які найбільш широко були відображені в засобах масової інформації [11; 12; 23], працях дослідників ЗКСУ [5; 10; 13] та низці опублікованих спогадів учасників подій $[12 ; 15 ; 22]$. Це збройні сутички за Слов'янськ, Маріуполь, Піски, Лисичанськ, Іловайськ, Савур-Могилу, Донецький аеропорт, Вуглегірськ (Дебальцево), Широкине. Беззаперечним є те, що згадані бої мали вплив на хід АТО.

Після захоплення Слов'янська озброєними спецпризначенцями російських окупаційних військ (далі - РОВ) 12 квітня 2014 року для визволення міста від терористів 14 квітня 2014 року було залучено аеромобільні підрозділи 25-ї, 79-ї, 80-ї і 95-ї аеромобільних бригад, а також сформований 1-й резервний батальйон від НГУ на основі добровольців із громадських формувань. Бійці цього резервного батальйону перебували на блокпостах i опорних пунктах навколо міста, щоб перешкоджати надходженню ресурсного поповнення для РОВ.

Водночас у Слов'янську та поблизу нього діяли групи беззбройних добровольців, які збирали інформацію про бойовиків та передавали іiі представникам сил АТО. Одну таку групу з трьох добровольців бойовики 
виявили 17 квітня у Слов'янську. Двох із них бойовики одразу вбили, а третього, як стало відомо пізніше, залишили живим і катували [7].

Група добровольців від ГО “Правий сектор”, яку очолював Д. Ярош, 3 19 на 20 квітня вирушила на гору Карачун біля Слов'янська, щоб зашкодити трансляції російських телеканалів та ворожій пропаганді, знищивши телевізійну вежу, утримувану російськими бойовиками. Формально очолював групу Д. Ярош, а фактично у бою - ветеран-афганець. Для досягнення раптовості було прийнято рішення провести акцію вночі. Після першої години ночі 20 квітня під час наближення до гори групу без попередження обстріляли російські спецпризначенці. Зав'язався бій. Бойовики швидко отримали підкріплення. Під тиском противника група українських добровольців вимушена була залишити місце бою. Завдання не було виконано.

Проте цей бій став відомий завдяки розтиражованому в російських засобах масової інформації повідомленню про участь українських “карателів" у боротьбі з “сепаратистами” Сходу України, адже в одязі убитого добровольця М. Станіславенка, тіло якого не змогли забрати побратими, знайшли візитку ГО “Правий сектор” [8, с. 280-283].

Перший відомий успішний бій великої самоорганізованої групи українських патріотів “Азов” був за звільнення Маріуполя від російських окупаційних військ і місцевих колабораціоністів 13 червня 2014 року спільно з підрозділами сектору безпеки і оборони України [4; 12].

14 липня 2014 року під час спланованого поетапного визволення населених пунктів у секторі “А” Луганської області підрозділами батальйонною тактичною групою (далі - БТГр) 80-ї оаембр, БТГр 128-ї огпбр, розвідувальною групою 8-го окремого полку спеціального призначення (далі - опСпП) та 24-го бТрО “Айдар” - було очищено від бойовиків населений пункт Щастя.

У секторі “Б”, реалізовуючи план взяття в оточення міста Донецьк, у липні 2014 року 93 омбр послідовно звільняла населені пункти, розміщувала 
блокпости. Так, 21 липня частина 93-ї омбр висунулася на штурм н.п. Піски, зайнятого бойовиками, які завчасно підготували позиції до кругової оборони. Бригаду в бою підтримували бійці українських добровольчих формувань MBC “Дніпро-1” та “Шахтарськ”. Цей укріплений район бойовиків у засобах масової інформації був названий “Республіка Міст”.

У той же час поблизу Пісків добровольчий батальйон “Донбас”, 5-та рота 93-ї омбр та бійці Добровольчого українського корпусу (ДУК) штурмували бойовиків, які захопили населений пункт Карлівку. Лише 24 липня 2014 року Піски остаточно було взято під контроль силами АТО [25].

24 липня 2014 року завдяки вдалій масштабній загальновійськовій операції у секторі “А” визволено сильно укріплене та насичене бойовиками місто Лисичанськ. В операції брали участь 1 БТГр 95-ї оаембр, 1 і 2 БТГр 24-ї омбр, БТГр 51-ї омбр, а також добровольчий батальйон “Донбас”. Під час визволення міста 24 липня спільно з бійцями 95-ї омбр діяв добровольчий батальйон НГУ “Донбас”, що зачищав місто від бойовиків у напрямку центру [24].

У червні 2014 року в секторі “Д” відбувся першій бій за курган СавурМогилу, який прийняли розвідники 3-го опСпП ЗС України. Для сил АТО бої за панування на кургані відбувалися зі змінним успіхом. Починаючи 3 29 липня 2014 року, сили АТО сектору “Д” провели кілька невдалих спроб вибити бойовиків із кургану Савур-Могила. Серед сил АТО, що штурмували н.п. Степанівка, діяв добровольчий загін із представників ДУК (позивний старшого - “Вольф”) [15, с. 50].

Доброволець загону “Харків” М. Музика пригадував, що на початку серпня було прийнято рішення створити зведену групу для участі у визволенні Савур-Могили під керівництвом полковника І. Гордійчука. Загін був сформований при 3-му опСпП із добровольців, які пройшли відповідну підготовку на навчальній базі. До зведеного підрозділу залучили бійців добровольчої групи “Харків” (командир - “Вихрь”), добровольчого 
батальйону “Луганськ” (командир - Т. Юлдашев) та добровольчого загону “Крим” (командир - I. Акаєв) [15, с. 50-64; 13, с. 69].

13 серпня 2014 року підрозділи сектору “А” (1 БТГр 80-ї оаембр, БТГр 24-ї омбр) зайняли зі сходу від Луганська н.п. Новосвітлівка і Хрящувате, тим самим перекрили забезпечення бойовиків по дорозі Луганськ Краснодон. Разом із силами сектору в операції брав участь 24-й бТрО “Айдар”, який за день зробив марш від Щастя протяжністю майже в 100 км і вступив у бій. Учасник тих подій боєць “Айдару” В. Скакун пригадував, що в Новосвітлівку заходило близько 130 бійців, а в Хрящувате - 80 бійців від 24 бТрО [19, с. 160-162].

20 серпня 2014 року підрозділи російських окупаційних військ у складі трьох рот із танками та броньованою технікою за підтримки артилерійського вогню прорвали оборону сектору “А” $з$ боку н.п. Розкішне у напрямку Георгіївки. Їх успішне та стрімке просування було зупинено поблизу м. Лутугине на висоті “Сармат”, яку героїчно разом із військовослужбовцями 9-ї роти 3 БТГр 24-ї омбр утримували бійці добровольчого батальйону МВС “Шторм”. Оборону очолював офіцер 24-ї омбр із позивним “Сармат”. Завдяки стійкості тих, хто оборонявся, сили АТО провели вдалу контратаку та завдали значних втрат окупаційним військам (що наступали) як у техніці, так і в живій силі [10].

Українські добровольчі формування ЗС України - 39-й і 40-й батальйони територіальної оборони - були серед основних сил сектору “Б”, що наприкінці липня та на початку серпня 2014 р. виконували завдання штабу АТО з оточення Донецька.

34 на 5 серпня командир 40-го бТрО О. Мотрий отримав наказ від керівника сектору висунутися до Іловайська, зачистити його від бойовиків $і$ встановити блокпости. Удень за підтримки бронегрупи 51-ї омбр вони вступили в бій за підступи до Іловайська. Групі вдалося знищити один укріплений район бойовиків, але далі просунутися не вдалося, тому бійці відійшли. 
Водночас у Дніпрі на чолі із заступником голови Дніпропетровської обласної державної адміністрації Г. Корбаном відбулася зустріч командирів добровольчих батальйонів: А. Білецького (батальйон “Азов”), А. Філоненка (“Шахтарськ”), Ю. Берези (“Дніпро-1”), С. Семенченка (“Донбас”). На зустрічі був присутній керівник сектору “Б” генерал-лейтенант Р. Хомчак, який охарактеризував обстановку в Іловайську. Учасники обговорили заходи взаємодії батальйонів із силами сектору щодо визволення Іловайська [16].

Після прибуття добровольчих батальйонів МВС та затвердження плану по штурму м. Іловайськ 18 серпня батальйони територіальної оборони вибили бойовиків із блокпостів, розташованих на околиці міста, та закріпилися там $[16$, с. 18,24$]$. Батальйони “Азов” і “Шахтарськ” увійшли в місто і потіснили бойовиків. Посеред Іловайська поблизу залізничних колій підрозділи “Азову” і “Шахтарська” наштовхнулися на укріплений район бойовиків, які шалено опиралися. Зав'язалися вуличні бої. Батальйони після перших боїв зазнали значних втрат, тому їх командири були вимушені вивести особовий склад 3 міста. У цей же час в Іловайськ увійшли бійці “Донбасу” та “Дніпро-1”, закріпилися та розпочали зачистку міста. На заміну батальйонам “Азов” і “Шахтарськ” прибули добровольчі формування МВС “Херсон”, “Світязь”, “Івано-Франківськ”, “Миротворець”. Зафіксовано, що 18 серпня 2-й взвод батальйону “Азов” надавав допомогу “Донбасу” та “Дніпру-1” [18]. Координацію добровольчих батальйонів у місті взяв на себе заступник командира батальйону “Донбас” В. Власенко (позивний “Філін”).

3 інформації РНБО України від 20 серпня 2014 року відомо, що місто Іловайськ звільнено від бойовиків та перебуває під контролем сил АТО. Дослідники встановили, що чисельність осіб, задіяних на початку визволення Іловайська, становила понад 940 бійців. За винятком бійців ротно-тактичної бронегрупи 51-ї омбр інші особи були бійцями українських добровольчих формувань [13, с. 118].

24 серпня 2014 року частина підрозділів 51-ї і 28-ї омбр та ротної тактичної групи 93-ї омбр (що прорвалися та приєдналися до групи 
українських військ, що були під Іловайськом) зазнали тиску 3 боку російських БТГр. 24 серпня на допомогу Іловайському угрупованню із пункту постійної дислокації направили БТГр 92-ї омбр та групу добровольців від 42-го бТрО "Рух опору”. Однак під час наближення до Іловайська ці підрозділи було остаточно оточено. Штаб командування АТО розробив план деблокування оточених українських військ, проте його не вдалося реалізувати, тому що 27 серпня підрозділи БТГр 92-ї омбр та зведений загін 42-го БТрО “Рух опору” були розбиті. Частина добровольців поблизу Новокатеринівки потрапила у полон [23].

Окремою сторінкою участі українських добровольчих формувань в ATO є бої за Донецький аеропорт (ДАП) з 26 травня 2014 року до 22 січня 2015 року. Спочатку бойові дії за ДАП вели військовослужбовці 3 опСпП і групи добровольців від ГО “Правий сектор”.

Опісля низки невдалих спроб захопити ДАП бойовики блокували захисників аеропорту. Однак 26 липня 2014 року українське угруповання сектору “Д” у складі 93-ї омбр та батальйонів псмоп “Дніпро-1” і “Шахтарськ” розблокували Донецький аеропорт.

Так, починаючи 34 жовтня, після того, як на територію ДАП для підсилення захисників зайшла група військовослужбовців від 95-ї оаембр, відбувся умовний розподіл відповідальності за об'єкти. Воїни 79-ї оаембр та бійці ДУК спільно утримували позиції у старому терміналі [13, с. 134].

Оборона аеропорту тривала до 22 січня 2015 року. 29 січня 2015 року командування сектору “А” здійснило спробу вибити бойовиків, які зайняли більшу частину м. Вуглегірська (за винятком південної, де ще перебували підрозділи МВС та ЗС України). Для цього залучили взвод із бронетехнікою від 30-ї омбр, спільно з яким активно діяли українські добровольчі формування: від НГУ - батальйон “Донбас" і батальйон імені С. Кульчицького, із представників яких сформовано зведену групу (70 осіб), від МВС - рота псмоп “Світязь” (39 осіб). Після полудня противник додатково ввів у бій свіжі резерви, внаслідок чого наступ українських 
підрозділів призупинився. У той самий час від командування сектору надійшов наказ про відхід підрозділів ЗС України та зведеної групи добровольчих батальйонів.

31 січня бойовики отримали допомогу у вигляді батальйонної тактичної групи, посиленої танками i легкою броньованою технікою. Загальна чисельність бойовиків становила майже 2000 осіб. Цього ж дня командир роти ппсмоп “Світязь” Олександр Парцевич, ввівши противника в оману, вивів із оточення ввірений особовий склад (який позитивно показав себе у бойових діях 29-31 січня 2015 р.). За героїчні та вмілі дії з оборони Вуглегірська, а також за вдалий відхід без втрат міністр внутрішніх справ нагородив 39 бійців роти ппсмоп “Світязь” (Волинська область), які з честю витримали тридобові безперервні бої [11].

Досвід участі українських добровольчих формувань у звільненні захоплених окупантами населених пунктів фіксують матеріали про Широкинську операцію, проведену з 10 по 16 лютого 2015 року. Основним організатором та учасником бою був добровольчий полк НГУ “Азов” (командир А. Білецький), чисельність якого на той час становила близько 800 осіб (хоча у бою взяла участь менша кількість бійців). 37 лютого 2015 року на озброєння полку надійшли шість бронеавтомобілів “Спартан”, оснащених інтегрованими комплексами, до складу яких входять пульти дистанційного керування і протитанкові керовані ракети. Ця система вогню здатна знищувати танки і вертольоти [18].

Додатковими силами, залученими до так званої Широкинської наступальної операції 10-15 лютого 2015 року, була частка від українських добровольчих формувань зі складу $\mathrm{MBC}$ : підрозділів патрульної служби міліції особливого призначення “Берда”, “Східний корпус", “Сокіл” і “Скіф”. Прогнозованою чисельністю особового складу, який брав від них участь у боях, було 30, 40, 15 та 50 осіб відповідно. Озброєння цих підрозділів було переважно стрілецьким. 
Від 2-го батальйону спеціального призначення “Донбас” НГУ надійшли на допомогу “Азову” спочатку взвод, а пізніше рота загальною чисельністю не більше 100 осіб, які мали при собі переважно легке озброєння. Крім того, був взвод танків від НГУ (3 од.) та 14 гаубиць від ЗС України (які вогнем підтримували бойові дії полку та доданих сил). У бойових діях також брав участь підрозділ морської піхоти 3 власними танками та БМП від ЗС України (чисельність яких встановити не вдалося).

Причинами прийняття рішення про проведення наступу, за спогадами А. Білецького, були: оточення українських військ противником навколо Дебальцевого; необхідність створення нової лінії оборони по р. Грузький Яланчик (що є природною перешкодою); обстріл російськими окупаційними військами спального району Маріуполя 24 січня 2015 року.

Однак є й інша точка зору щодо боїв за Широкине. Так, генерал армії України В. Муженко, будучи тоді начальником Генерального штабу 3С України, в інтерв’ю 31 серпня 2015 року зазначив: “Зимовий наступ на цей населений пункт був більше піар-акцією, ніж військовою операцією”, тому що “в українських сил є лінія оборони на висотах за Широкиним, і контроль над цими висотами дозволяє успішно реагувати на загрози Маріуполю” [14].

Під ранок 10 лютого 2015 року особовий склад полку “Азов” і доданих сил завантажився на техніку, приховано висунувся на напрямку наступу і почав бойові дії [22, с. 37]. 1-ша рота визволила н.п. Павлопіль, водночас 2-га рота та частина добровольчого формування МBC “Східний Корпус" визволила Широкине, маючи незначний вогневий контакт із бойовиками, які не очікували нападу i швидко відступили. 3-тя рота зайшла в н.п. Комінтернове, де противника застали зненацька, він не чинив опору i стрімко відступив [22, с. 35].

Після визволення Широкиного 2-га рота полку виконувала завдання 3 визволення Саханки від бойовиків. Ворог очікував добровольців, тому встиг додатково перемістити бойову техніку, артилерію та піхоту 3 н.п. 
Новоазовськ у Саханку. Під тиском переважаючих сил ворога особовий склад роти, не маючи підтримки, був вимушений відійти до Широкиного.

Наприкінці 10 лютого командування полку прийняло рішення населені пункти Комінтернове та Павлопіль залишити цього ж вечора, а Широкине продовжувати утримувати. Так, 3-й роті було поставлене завдання облаштувати на околицях визволеного н.п. Лебединське дозори та укріплення, щоб перешкодити противнику в наступі з н.п. Заїченко на Широкине. Крім цього, з Лебединського особовий склад підрозділу міг робити розвідки-вилазки і непокоїти ворога.

Протягом 11 лютого полк “Азов” утримував Широкине і Лебединське та проводив заходи 3 укріплення позицій. Противник накопичував сили $\mathrm{i}$ засоби та не вів активних дій, за винятком обстрілу артилерією позицій 2-ї роти. Очевидець, боєць 2-ї роти з позивним “Танцор”, пригадував, що на командному пункті “Маяк” в Широкиному він спільно з представником від артилерії корегував артилерійський вогонь доданих від ЗС України 14 гаубиць [22, с. 36].

12 і 13 лютого противник продовжував інтенсивно обстрілювати артилерією позиції полку в Широкиному, а в перервах між обстрілами провів три атаки, які бійці українських добровольчих батальйонів успішно відбили, a, крім того, провели дві контратаки. 12 лютого від НГУ у тактичне підпорядкування полку “Азов” надійшов взвод танків (3 од.), який відразу направили до Широкиного. Цього ж дня відбулася ротація бійців 3-ї роти, які перебували на позиціях поблизу Лебединського, на бійців 1-ї роти [22, с. 44].

Наступного дня бойовики спромоглися на масований, проте неуспішний для них контрнаступ. Наприкінці дня 13 лютого від добровольчого батальйону НГУ “Донбас” взвод прийшов на позиції, зайняті 2-ю ротою.

За період 10-13 лютого противник зібрав достатні сили і о 6 годині ранку 14 лютого 2015 року розпочав рішучий наступ з боку Саханського перехрестя на Широкине. Очевидець, командир взводу (позивний "Ковбой”) 
3-ї роти полку “Азов”, пригадує, що вранці 14 лютого 2014 року був отриманий наказ на переміщення взводу в Широкине для допомоги 2-й роті. У Широкине підрозділ прибув на БТР і бронеавтомобілі “Спартан” приблизно опівдні, коли настало певне затишшя під час бою.

Через наявність великої кількості бронетехніки, майже батальйону піхоти та ведення шквального артилерійського вогню противник просунувся майже до центру населеного пункту, де його зупинили лише жертовність і героїзм українських бійців. Зав'язалися вуличні бої. Відстань між протиборчими сторонами становила подекуди кілька десятків метрів. Представники російських окупаційних військ зрозуміли, що далі просунутися не зможуть і почали закріплюватися на захопленій території.

У ніч 314 на 15 лютого командування добровольчого полку “Азов” провело заходи з накопичення сил і засобів для вибиття бойовиків із Широкиного та подальшої зачистки. Так, на позиції 2-ї роти було направлено частину особового складу 1-ї роти. За спогадами бійців полку відомо, що там були представники морської піхоти 3 власними танками та БМП від ЗС України [22, с. 42], взвод від батальйону “Донбас", а також українські добровольчі формування від МВС “Берда" та “Східний корпус". О 6 год ранку 15 лютого було розпочато наступ зведеної групи на позиції бойовиків. Однак група потрапила в засідку, зазнала втрат і зупинилася. Бойовики відразу ж розпочали контрнаступ наявною у них бронетехнікою.

У цей критичний момент на підтримку бійцям полку “Азов” прибули два танки. Командування полку виявило, що підтримувати зв’язок із екіпажами танків неможливо через відсутність необхідних засобів зв'язку. За спогадами керівника того бою, командира 2-ї роти з позивним “Кірт”, відомо таке: “У нас були, скажімо, живі транслятори. Це були наші хлопці, азовці. Вони 3 раціями в руках стояли біля танка і передавали командиру мої накази”. Завдяки умілим діям екіпажів танків противнику було завдано втрат і він послабив натиск. 
Щодо участі у боях за Широкине 310 до 15 лютого 2015 року добровольчого батальйону “Берда” є згадка бійця розвідувально-диверсійної чоти полку “Азов” (позивний “Абдула”), який у розпалі бою зустрів групу особового складу цього добровольчого батальйону. Побачивши розгубленість бійців, він з'ясував, що це їхній перший бій, допоміг їм зорієнтуватися на місцевості та зайняти позиції в окопах для бою. Абдула пригадував: “Вони говорили, що такого їх не вчили. Законів учили, а як бігати з СПГ не вчили, не вміли вони ним користуватися” [20, с. 200-208].

Наприкінці 15 лютого частина особового складу добровольчого батальйону “Донбас” проводила ротацію особового складу полку “Азов”, виснаженого кількаденними боями на бойових позиціях Широкиного. Очевидці бою зазначили, що на той час були складні погодні умови, туман ускладнював видимість. Одна група “Донбасу”, дотримуючись інструкцій, вдало вийшла на позиції, зайняті “Азовом”, інша - відбилася від колони, збилася 3 правильного шляху та вийшла на позиції противника. Це місце стало ще й епіцентром бою. Група зазнала втрат: двоє бійців загинули, троє зазнали поранень [9]. Командування полку “Азов”, дізнавшись, що частка батальйону “Донбас" потрапила у скрутне становище, направило окрему групу із “азовців” для визволення “донбасівців”. Група успішно виконала завдання.

Починаючи 316 лютого 2015 року, бої у Широкиному набули позиційного характеру: активно застосовувалася артилерія, противник мінував території, діяли диверсійно-розвідувальні групи.

Таким чином, роль українських добровольчих формувань у боях під час збройного конфлікту на Сході України (квітень 2014 - лютий 2015 роки) слід оцінювати неоднозначно. Найбільших успіхів у бойовій діяльності українські добровольчі формування досягали у боях проти підрозділів, укомплектованих із місцевих колабораціоністів та парамілітарних російських формувань, рівень озброєння та підготовки яких був не набагато вищим, аніж у бійців УДФ. Успішності добробатів у боях проти регулярних російських 
окупаційних військ сприяла бойова підтримка військових частин (підрозділів) 3С України. Невисока якість навченості особового складу, наявність лише стрілецької зброї та недостатнє матеріально-технічне забезпечення цих формувань компенсувалися ініціативністю та високою вмотивованістю бійців. Також під час боїв добровольчі батальйони нарівні 3 регулярними частинами застосовували як штурмові підрозділи під час звільнення територій від окупантів.

\section{Список використаних джерел і літератури}

1. Гуральська A. Звіт: Добровольчі батальйони. Виникнення, діяльність, суперечності: [Електрон. ресурс]. - Режим доступу: http://ua.odfoundation.eu/a/6444,zvit-dobrovolchi-batalyoni-viniknennyadiyalnist-superechnosti (дата звернення: 15.06.2019).

2. Косовська А. “Фортуна”, доброволець АТО. Добровольчий рух України. Хронологія війни: [Електрон. ресурс]. - Режим доступу: https://alinafortuna. com/2016/05/04/добровольчий-рух-україни-хронологія/

3. Аналіз ведення антитерористичної операції та наслідків вторгнення Російської Федерації в Україну у серпні-вересні 2014: [Електрон. ресурс]. Режим доступу: http://www.mil.gov.ua/content/other/anliz_rf.pdf (дата звернення: 15.06.2019).

4. Белозерская E. Освобождение Мариуполя от боевиков “ДНР”: как это было // Факты.ictv.ua. - 2018. - 13 червня: [Електрон. ресурс]. - Режим доступу : https://fakty.ictv.ua/ru/ukraine/20180613-zvilnennya-mariupolya-vidbojovykiv-dnr-yak-tse-bulo/ (дата звернення: 15.06.2019).

5. Біла книга антитерористичної операції на Сході України (20142016). - Київ : НУОУ, 2017. - 250 с.

6. Бутусов Ю. Добровольчі батальйони: структура, страхи, проблеми бойового застосування: [Електрон. ресурс]. - Режим доступу: http://gazeta.zn.ua/internal/dobrovolcheskie-batalony-struktura-strahi-problemyboev 
7. Бутусов Ю. Дмитро Ярош: “Перший наступальний бій війни відбувся 20 квітня 2014-го - добровольці атакували блокпост під Слов'янськом": [Електрон. ресурс]. - Режим доступу :

https://ua.censor.net.ua/resonance/385673/dmytro_yarosh_pershyyi_nastupalnyyi_ biyi_viyiny_vidbuvsya_20_kvitnya_2014go_dobrovoltsi_atakuvaly_blokpost (дата звернення: 15.06.2019).

8. Добробати / [К. Гладка, Д. Громаков, В. Миронова та ін.]. - Харків : Фоліо, 2016. - 570 с.

9. “Донбас" потрапив у засідку під Маріуполем: 2 бійці загинули: [Електрон. ресурс]. - Режим доступу : https://ukr.lb.ua/society/2015/02/15/295674_donbas_potrapiv_zasidku_pid.html (дата звернення: 15.06.2019).

10. Злочин і кара. Бій 20 серпня 2014 року: [Електрон. ресурс]. Режим доступу : https://feldherrnhalle.livejournal.com/10806.html (Дата опублікування: 14.07.2016).

11. Коваленко C. Вистояли й вирвалися 3 ворожого кільця / С. Коваленко // Іменем закону. - 2015. - 12 лютого. - № 6. - С. 3.

12. Командир “Азову” розповів, як “зачищали” Маріуполь: [Електрон. ресурс]. - Режим доступу : https://www.pravda.com.ua/news/2014/06/16/7029205/ (дата звернення: 15.06.2019).

13. Марко С. Хроника гибридной войны / С. Марко. - К. : Альтерпрес, 2016. $-248 \mathrm{c}$.

14. Муженко заявив, що село Широкино не має військової цінності: [Електрон. ресурс]. - Режим доступу : https://ukr.lb.ua/society/2015/02/15/295674_donbas_potrapiv_zasidku_pid.html (дата звернення: 15.06.2019).

15. Музика M.I. Савур-Могила. Військові щоденники / М. І. Музика, А. М. Палваль, П. Г. Потєхін; пер. 3 рос. С. А. Заяць; худож.-оформлювач Н. В. Величко. - Харків : Фоліо, 2017. - 316 с. 
16. Павлюк $A$. Іловайська трагедія: події та відповідальність / А. Павлюк // Українська Гельсінська спілка 3 прав людини. - 2016. - 34 с.: [Електрон. ресурс]. - Режим доступу: https://helsinki.org.ua/wpcontent/uploads/2016/09/Yllowaysk_UGSPL-1.pdf.

17. Перепелиця Г.М. Україна - Росія: війна в умовах співіснування / Г. М. Перепелиця. - Київ : Видавничий дім “Стилос”, 2015. - 880 с.

18. Полк “Азов” получил бронеавтомобили “Спартан”, способные поражать танки и вертолеты: [Електрон. ресурс]. - Режим доступу: http://gordonua.com/news/war/polk-azov-poluchil-broneavtomobili-spartansposobnye-porazhat-tanki-i-vertolety-65317.html (дата звернення: 15.06.2019).

19. Розуменко B. Нескорені : інтерв'ю із Героями АТО / В. Розуменко. - Київ : ВЦ “Просвіта”, 2016. - 368 с.

20. Стасюк Ю.М. Українські добровольчі формування: створення та функціонування (2014-2015 рр.) : Дис. ... канд. іст. наук : 07.00.01. - К., 2018. $-281 \mathrm{c}$.

21. Турчинов на презентації книги “Добробати”: [Електрон. ресурс]. Режим доступу : http://ua.censor.net.ua/photo_news/425325/dobrovolchi batalyionyzaklalyideologiyur ozvytkusylnoyipatriotychnoyinezalejnoyikrayinytur chynov.

22. Широкинська операція. Спогади учасників наступу/ [упоряд. М. Хомеріккі]. - Київ - Маріуполь - Мена : Домінант, 2016. - 72 с. - (Серія “Азовські спогади”).

23. Як 42-й батальйон тероборони намагався деблокувати Іловайський котел (Фото): [Електрон. ресурс]. - Режим доступу: http://old.gre4ka.info/suspilstvo/20935-yak-42-i-batalion-teroborony-namahavsiadeblokuvaty-ilovaiskyi-kotel-foto (дата звернення: 15.06.2019).

24. Як десантники 95-ї оаембр здійснили найдовший рейд у військовій історії світу // Експрес. - 2017. - 20 липня: [Електрон. ресурс]. - Режим доступу : http://expres.ua/news/2017/07/20/253302-desantnyky-95-yi-oaembrzdiysnyly-naydovshyy-reyd-viyskoviy-istoriyi-svitu. 
25. Як рік тому українські бійці звільняли Піски (Фото): [Електрон. peсурс]. - Режим доступу: https://www.depo.ua/ukr/war/yak-rik-tomuukrayinski-biytsi-zvilnyali-piski-foto--26072015233900 (дата звернення: 15.06.2019).

Stasiuk Yu.M., Candidate of Historical Sciences, Head of Research Laboratory of Research Center of Military History of Ivan Cherniakhovskyi National Defense University of Ukraine (Kyiv);

Horielov V.I., Candidate of Historical Sciences, Senior Researcher of Research Laboratory of Research Center of Military History of Ivan Cherniakhovskyi National Defense University of Ukraine (Kyiv)

\section{THE ROLE OF UKRAINIAN VOLUNTEER FORMATIONS IN BATTLES ON THE EAST OF UKRAINE (APRIL 2014 - FEBRUARY 2015)}

Based on the study of unclassified multifaceted literature, it is revealed that there is no generalized material on the participation of Ukrainian voluntary units in battles in eastern Ukraine. The Article in question specifies why it is reasonable to refer to "Ukrainian Volunteer Units" as a sole term. Following a thorough analysis of materials available the Author of this Article identified a set of common features (descriptors) Ukrainian Volunteer Units are characterized by, as well as defined the term in question. The main fights in which the voluntary units took part were separated from the anti-terrorist operation. On this basis, the authors consider the role of formations during the battles, determine the conditions that contributed to the success of their activities.

Keywords: Ukrainian volunteer formation, volunteer battalions, combat operations, fighting, anti-terrorist operation in eastern Ukraine. 